\title{
The future of education according to the fourth industrial revolution
}

\author{
Shaher Elayyan ${ }^{\mathrm{a} *}$ (D) \\ ${ }^{\text {aS }}$ ohar University, Oman.
}

Suggested citation: Eleyyan, S. (2021). The future of education according to the fourth industrial revolution. Journal of Educational Technology \& Online Learning, 4(1), 23-30.

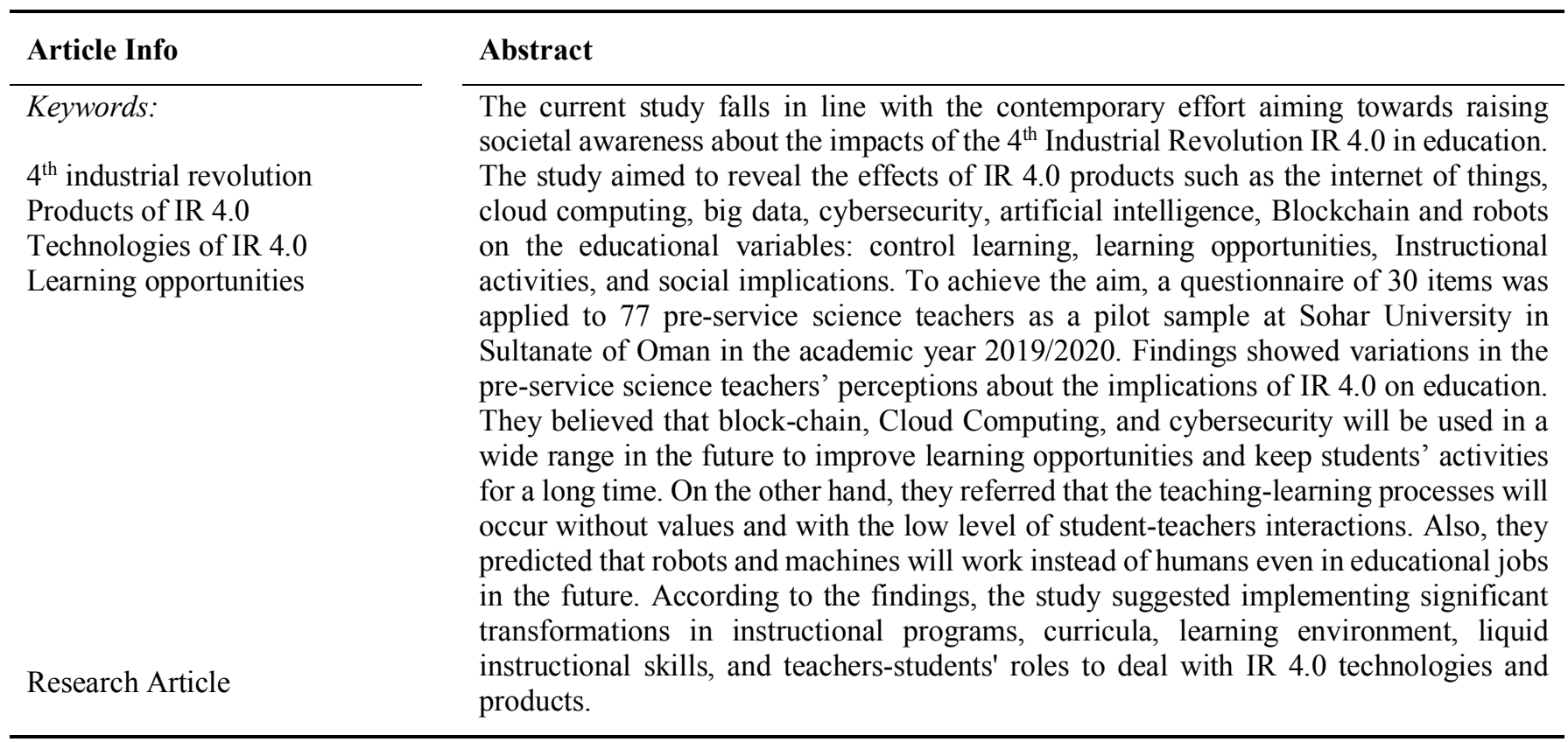

\section{Introduction}

The Industrial Revolutions appeared as a result of developing science, technology, and community culture; they aim to improve human life. Each revolution has its characteristics and implications. The first industrial revolution IR 1.0 started at the end of the 19th century passed through the introduction of mechanical production facilities powered by water and steam. The second one IR 2.0 which started at the beginning of the 20th century dealt with mass production assembly lines requiring labour and electrical energy. While the third industrial revolution IR 3.0 which appeared in the 70ies of the 20th century characterized by applying automated production using electronics and information technology (Dino \& Ong, 2019; Gleason, 2018). Currently, humans try to accommodate the fourth industrial revolution IR 4.0 which is defined briefly as the vital interaction between human and machines (Lee, Yun, Pyka, Won, Kodama, Schiuma, Park, Jeon, Park, Jung, Yan, Lee \& Zhao, 2018).

A lot of products and technologies formed the main features of IR 4.0. Internet of Things IoT is an example is internet-connected sensor embedded in products such as vehicles and home appliances that allow these things to connect, interact and exchange data. The global IoT market is expected to reach $\$ 19$ trillion by 2020, with 26 billion embedded devices (Waghid, Waghid \& Waghid, 2019). Another example of IR 4.0 products is Cloud Computing which refers to the use of a network to host massive volumes of data collected

\footnotetext{
* Corresponding author: Shaher Eleyyan. Sohar University, Oman.

e-mail addresses: se72sc@gmail.com
} 
by IoT systems on the internet rather than on your personal computer. Analysis of this Big Data leads to smarter business decisions and drive innovations (Menon \& Castrillon, 2019; Neves \& Ambassador, 2017). Artificial Intelligence AI is also an example of IR 4.0 products which are formed by computer science learning algorithms capable machines like robots to perform complex tasks such as visual perception, speech recognition, and decision making (Liaoa, Louresa, Deschampsa, Brezinskia \& Venancioa, 2018; Mezied, 2016).

According to IR 4.0, technologies are fused and there are no solid lines between the physical, digital, and biological aspects of life. Nowadays, IR 4.0 is immersed in most active sectors such as industry, agriculture, medicine, and economics. Also, IR 4.0 technologies are predicted to have an impact on the 2030 Sustainable Development Goals such as good health, clean water and sanitation, clean energy, sustainable cities, and climate action (Min, Kim, Lee, Jang, Kim \& Song, 2019).

The educational system is not isolated from IR 4.0 technologies which are predicted to have a significant effect on learning opportunities, educational policies, and instructional procedures(Al Lily, Elayyan, Alhazmi \& Alzahrani, 2018). Changing starts from schools and universities when they design a suitable program and curricula that matching with employment. World Economic Forum (2018) referred that 65\% of the students in school today will work in jobs that do not currently exist and $47 \%$ of today's jobs will be automated in the next decade. Also, until 2020 more than $50 \%$ of the content in a graduate degree will be useless in 5 years. These data excite experts and educators to research more and more to suggest methods and strategies that ensure quantitative and qualitative learning that helps the students to face the future (Schwap, 2016).

The fourth Industrial Revolution IR 4.0 will accelerate the rate of disruption in jobs which we are already experiencing and it is necessary to empower individuals to take charge of their education and career strategies (Reaves, 2019). World Economic Forum reports that IR 4.0 requires reshaping the future of education and work to diversify talents (Yang, 2019). So, Organizations need to have a successful strategy and adopt new products of IR 4.0 such as big data, blockchain technology and artificial intelligence in education instead of traditional procedures (Shahroom \& Hussein, 2018; Ceylan, 2020). Janikova \& Kowalikova (2017) considered that the key role in the future is summarized by ensuring long-life learning and providing individuals with experiences about the dynamic market and socio-economic changes. While Sharma (2019) emphasized that when we teach our students according to IR 4.0, we must preserve our core attributes, our ethical standards, and our way of life. Also, she considered that the transformation of higher education is a key factor in the digital transformation of IR 4.0.

\subsection{The Problem Statement}

Most education systems in the world start changing their educational policies and plans to prepare the students for the mysterious future where a new type of jobs that we can't even imagine today and new technologies that most of us have never even dream about(Kim, 2017; Lodder, 2016).

Sultanate of Oman is a country that tries to work hard to develop its education system. It is always revising and reviewing science curricula to provide the students with all competencies and skills that qualify them for future life challenges and industrial revolutions. From the belief that IR 4.0 stresses technology in every aspect, Omani policy adopting IR 4.0 ideas according to four main steps: awareness, training, deployment, and innovation. In Education, the Omani Ministry of Education's General Directorate of Education in the Governorate of North Al Batinah hosted the first conference entitled "The International Conference of the Fourth Industrial Revolution and its impact on education" in Sohar in the time interval 21st to 23rd January 2019. Many papers were discussed to suggest the best methods to reconstruct our educational systems and programs for IR 4.0 (Elayyan \& Al-Shizawi, 20.19). 
The current study falls in line with the world's efforts which aim to redirect teaching and learning processes toward IR 4.0 products and technologies. Specifically, this study tries to predict the future of education according to IR 4.0 from pre-service science teachers' point of view at Sohar University.

\section{Methodology}

The current study applied the quantitative survey design which "involves data to test hypotheses or to answer questions about people's opinions on some topic or issue" (Gay, Mills, \& Airasian, 2013, 184). The sample consists of 77 pre-service science teachers in the Teacher Preparation Program TPP at Sohar University in the academic year 2019/2020. All individuals in the sample were female with 22-24-yearolds. They were chosen in a pilot technique because they graduated with a bachelor in physics, chemistry, and biology before attending TPP. So, they have a good background in science and technology which qualified them to react toIR 4.0 ideas and products.

\subsection{Data Collection Tool}

The current study applied the quantitative survey method with a questionnaire as the main tool to collect data. The questionnaire was constructed by revising the related literature (Butler, 2018; Dino \& Ong, 2019; Elayyan, 2016 \& Sharma, 2019). Then, constructing a draft copy of 32 items that were distributed into four dimensions: control learning, learning opportunities, content, and instructional activities, and social implications. To check validity, the questionnaire was submitted to 18 specialists in science curricula, Instructional technology, and also submitted to science supervisors to put their notes about the suitability and accuracy of items to be applied. After collecting the experts' point of views and implemented their modifications, 2 of these items were deleted and the final version of the questionnaire consisted of 30 items ( 7 items for $\mathrm{d}$ control learning, 9 for learning opportunities, 9 for content and instructional activities, 5 for social implications) with 5 points Likert scale (strongly agree $=5$, agree $=4$, neutral $=3$, disagree $=2$, strongly disagree $=1$ ). Finally, to check reliability, the final version of the questionnaire was applied to a pilot sample of 25 pre-service teachers out of the study sample, then calculate the self-constancy by Cronbach's Alfa formula, the value was 0.89 which means that the study tool, as in appendix, as applicable.

\section{Findings and Discussions}

Study findings were obtained after applying the questionnaire to the sample of pre-service science teachers. The averages and standard deviations were calculated for each item in the questionnaire. Also, intervals of a typical 5 point Likert scale were calculated to determine the pre-service science teachers' perceptions ratio about implications of applying IR 4.0 in education as in the following: calculating the Range (max. score - min. score $=5-1=4)$, then calculating the category interval ( $=$ Range/max. score $=4 / 5=0.8)$, so we have 5 intervals as shown in table 1.

Table 1.

Teachers' perceptions of degrees vs. average intervals of the questionnaire items

\begin{tabular}{cc}
\hline Average Interval & Perception's ratio \\
\hline $1.0-1.8$ & Very low \\
$>1.8-2.6$ & low \\
$>2.6-3.4$ & intermediate \\
$>3.4-4.2$ & high \\
$>4.2-5.0$ & Very high \\
\hline
\end{tabular}

Also, averages were transformed to Percentages of perception from the equation: Percentage $=[($ Average $-1) /$ Range $] \times 100 \%$. Data were collected and then arranged in table 2 to discuss the study question. 


\section{Table 2.}

Averages and standard deviations of pre-service science teachers' perceptions about education according to IR 4.0

\begin{tabular}{ccccc}
\hline Items & Average & $\begin{array}{c}\text { Standard } \\
\text { Deviation }\end{array}$ & $\begin{array}{c}\text { Percentage of } \\
\text { availability }\end{array}$ & $\begin{array}{c}\text { Rank } \\
\text { perception } \\
\text { Ratio }\end{array}$ \\
\hline
\end{tabular}

\section{Applying IR 4.0 in education will:}

\section{Dimension1: Control Learning}

\begin{tabular}{|c|c|c|c|c|c|c|}
\hline 1 & decrease Teacher's attendance to the school & 3.74 & 1.58 & $68.59 \%$ & 5 & high \\
\hline 2 & $\begin{array}{l}\text { keep the humanity interactions between teachers and } \\
\text { students }\end{array}$ & 1.77 & 1.49 & $19.23 \%$ & 7 & Very low \\
\hline 3 & increase classroom management & 4.59 & 1.04 & $89.74 \%$ & 3 & Very high \\
\hline 4 & verify of the students' files anywhere by Block-Chain & 4.77 & 0.79 & $94.23 \%$ & 2 & Very high \\
\hline 5 & $\begin{array}{l}\text { improve decisions toward students by using artificial } \\
\text { intelligence }\end{array}$ & 2.05 & 1.60 & $71.15 \%$ & 6 & low \\
\hline 6 & $\begin{array}{l}\text { keep students' activities and duties for a long time by } \\
\text { using Cloud Computing }\end{array}$ & 4.87 & 0.59 & $96.79 \%$ & 1 & Very high \\
\hline \multirow[t]{2}{*}{7} & keep student's data safety by using cybersecurity & 4.33 & 1.23 & $83.33 \%$ & 4 & Very high \\
\hline & & 3.73 & 0.76 & & & \\
\hline
\end{tabular}

\section{Dimension 2: Learning Opportunities}

\section{Applying IR 4.0 in education will:}

\begin{tabular}{|c|c|c|c|c|c|c|}
\hline 8 & increase the experiences exchange & 4.41 & 1.17 & $85.26 \%$ & 7 & Very high \\
\hline 9 & provide more learning resources and database & 4.87 & 0.59 & $96.79 \%$ & 2 & Very high \\
\hline 10 & allow learning anytime and anywhere & 4.87 & 0.59 & $96.79 \%$ & 2 & Very high \\
\hline 11 & support more opportunities in individual learning & 4.77 & 0.85 & $94.23 \%$ & 5 & Very high \\
\hline 12 & support more opportunities in social learning & 2.85 & 1.67 & $46.15 \%$ & 9 & intermediate \\
\hline 13 & $\begin{array}{l}\text { enhance Global learning (No boundaries and no } \\
\text { restrictions) }\end{array}$ & 4.82 & 0.66 & $95.51 \%$ & 4 & Very high \\
\hline 14 & achieve long-life learning & 4.56 & 1.05 & $89.10 \%$ & 6 & Very high \\
\hline 15 & $\begin{array}{l}\text { extend the learning platforms instead of the typical } \\
\text { school }\end{array}$ & 4.90 & 0.55 & $97.44 \%$ & 1 & Very high \\
\hline 16 & $\begin{array}{l}\text { help to produce nano-robots to inter them inside the } \\
\text { student's brain to improve his motivation toward } \\
\text { learning }\end{array}$ & 3.67 & 1.50 & $66.67 \%$ & 8 & high \\
\hline & & 4.41 & & & & \\
\hline \multicolumn{7}{|c|}{ Dimension3: Content and instructional activities } \\
\hline \multicolumn{7}{|c|}{ Applying IR 4.0 in education will: } \\
\hline 17 & ensure commitment to educational ethics & 2.72 & 1.57 & $42.95 \%$ & 9 & Very low \\
\hline 18 & modify in instructional strategies & 4.64 & 0.95 & $91.03 \%$ & 3 & Very high \\
\hline 19 & Change the courses' learning outcomes & 4.44 & 1.20 & $85.90 \%$ & 5 & Very high \\
\hline 20 & $\begin{array}{l}\text { adopt the integrated curricula (i.e. No boundaries } \\
\text { between curricula) }\end{array}$ & 4.36 & 1.23 & $83.97 \%$ & 6 & Very high \\
\hline 21 & $\begin{array}{l}\text { allow Robots to teach inside the classroom instead of } \\
\text { lecturers }\end{array}$ & 4.49 & 1.18 & $87.18 \%$ & 4 & Very high \\
\hline 22 & apply non-biasing e-evaluation & 4.31 & 1.24 & $82.69 \%$ & 7 & Very high \\
\hline 23 & understand more and more instructional content & 4.18 & 1.27 & $79.49 \%$ & 8 & high \\
\hline
\end{tabular}




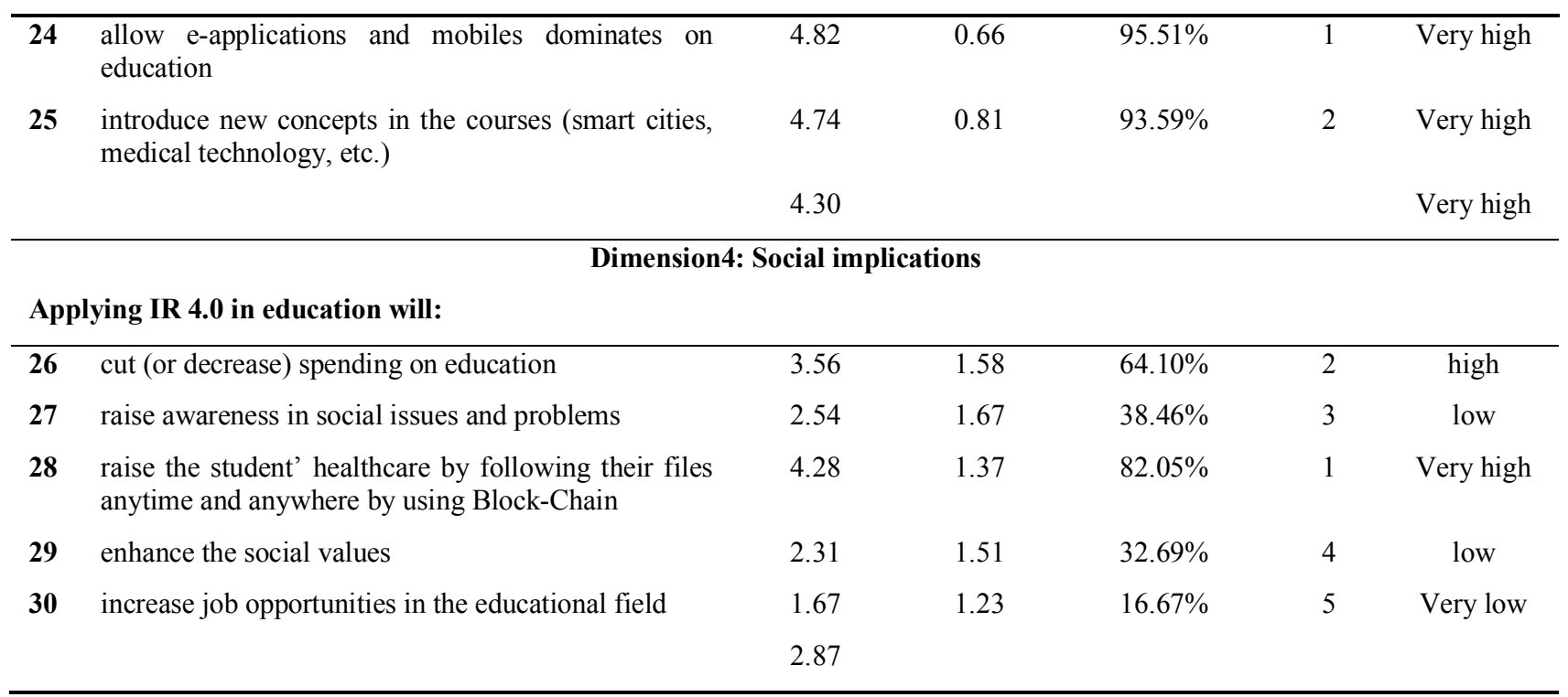

Table 2 shows the pre-service science teachers' perceptions about applying IR 4.0 in education. The total average for dimension 1 "control learning" was $\mathrm{m}=3.73$ and the averages' range $1.77-4.87$. This result reflects the awareness-raising of IR 4.0 technologies and products in education. The pre-service science teachers believe that block-chain, cloud computing, and cybersecurity will be used in a wide range in the future to keep student's data and activities for a long time. On the other hand, they have very low perceptions about the humanity reactions between teachers and students as in item 2 which has an average $\mathrm{m}=1.77$. This means that the student will interact with the machine more than humans (teachers, supervisors, and classmates). Also, the pre-service science teachers have low perceptions about item 2 which states that "Improve decisions toward students by using artificial intelligence" with an average $\mathrm{m}=$ 2.05. This result refers that the teacher will have strong decisions about the students' marks and behaviors.

Table 2 also shows the total average $m=4.41$ and averages' range (2.85-4.90) for dimension 2 "learning opportunities". According to these results, the pre-service science teachers believe that applying IR 4.0 will improve learning opportunities by providing more learning resources and database, allowing learning anytime and anywhere, enhancing global learning, and achieve long-life learning where these statements have high averages with values $(\mathrm{m}=4.87,4.87,4.82,4.56)$ respectively. The results show that there are differences in perceptions about the role of IR 4.0 in social learning and individual learning. In item 12 the average was $\mathrm{m}=2.85$ while in item 11 the average $\mathrm{m}=4.77$ which means that IR 4.0 technologies and products support individuals more than social learning which is compatible with the previous result that relevant with low human interactions.

For dimension 3 "content and instructional activities", the findings show that IR 4.0 will cause a true revolution in instructional strategies, learning outcomes, and non-biasing e-evaluation where these indicators in items $18,19,22$ have high averages $\mathrm{m}=4.64,4.44,4.31$ respectively. The findings also refer that the teachers will have more instructional aids such as robots, mobiles, and other e- applications that help to understand the educational situations not only verbally but also visually which reflects positively on motivation and interest to learn. The lowest average in this dimension was for item 17 which is stated that "ensure commitment to educational ethics", which means that there is no control on educational system and processes according to IR 4.0 applications.

Finally, findings that related to dimension 4 "social implications" show the averages' range (1.67-4.28) which means variation in pre-service science teachers' perceptions. They believe that applying IR 4.0 technologies will raise the students' healthcare by following their files anytime and anywhere by using block-chain as in item 28 with the highest average $m=4.28$. But, they showed low perceptions about the 
capability of IR 4.0 technologies to raise awareness in social issues and problems and enhance social values. This result reflects the belief that robots and artificial intelligence help to decide according to the input data but it is impossible to have emotional skills to understand attitudes and values. Item 30 which stated that "applying IR 4.0 in education will Increase job opportunities in educational field" has the lowest average $\mathrm{m}=1.67$ which means that the pre-service science teachers believe that in the future robots and machines will work instead of humans even in educational jobs.

\section{Conclusions and Suggestions}

Based on the findings of the current study, the pre-service science teachers showed variations in their point of view about the implications of IR 4.0 on education. This means that educators should understand the positive side and also negative sides when they deal with IR 4.0 to design teaching and learning processes. Even if there are disadvantages (or negative sides) of IR 4.0, it is important to apply its technologies and products in education to qualify students who have competencies and skills to understand the future challenges and try to solve them.

To achieve that it is important to ensure integration between disciplines as in Science, Technology, Engineering and Mathematics STEM approach and also integration between the educational system elements (educational policy, teachers, curricula, learning environment, and students) and industrial sectors in society. This integration helps to design curricula and instructional activities that qualify the students to have future jobs, because in the future the problem could not be the lack of jobs but the shortage of skills that will depend completely on IR 4.0 ideas. In the future we will lose a lot of jobs such as typical engineers, programmers, typical doctors, waiters, etc. and new jobs will appear such as robot technicians, big data investigators, artificial intelligence experts, blockchain designers, and 3D printing engineers.

On the other hand, it is important to activate student-centered learning. To achieve that it is important to measure the students' learning style and multiple- intelligence to transform classrooms from old-fashioned to flexible. A flexible classroom allows during a specific time to implement more than one event compatible with visual, verbal, and kinesthetic students. This paradigm helps to improve the student's learning according to their interests and abilities which lead to too long life learning and dealing with the future's technology easily.

Another procedure that helps to prepare the students for the IR 4.0 is the transformation from knowledge skills to liquid or soft skills. Reading comprehension, writing expressions, and mathematical reasoning are not valid skills to have a job in the future. It is important to develop the students' right-brain skills to have other types of skills such as technical skills, critical thinking, coordinating with others, verbal communications, and time management. These soft skills will be fundamentals and the basic requirements to deal with IR 4.0 technologies and ideas. Also, It is necessary, nowadays, to improve digital skills such as blogging, filming, podcasting, wiki building and uploading by preparing a virtual learning environment (VLE) as a platform to facilitate e-learning and enable the students to design and online delivery of modules (Molotsi, 2020).

In the same context, it is important to revise our learning outcomes and curricula content. Also, how the scientific content design and deliver to the students. In the future it is not probable to still presenting content by text (written) books; Massive Open Online Courses (MOOCs) will be an active substitution in the future. MOOCs are a potentially disruptive innovation and match with IR 4.0 technologies and the global job markets' needs. The number of MOOCs are increasing exponentially across the globe, making learning more accessible to people. Also, the number of participants has doubled in 2015 from 18 million students to 35 million students across all MOOC providers; even universities are digitizing some of their courses (Reaves, 2019).

On the other hand, using MOOCs and other educational platforms allow to adopt Student's Global Identity, which is a portable and secure card that stores individual information and can be used across countries 
especially in cases of conflict eruption, natural disaster, and coronavirus (covid-19) pandemic. During covid-19 which is declared as a pandemic on 11 march 2020, all countries start learning online and applying technology in education. Time by time this type of learning will be an educational culture and maybe an alternative to traditional learning. IR 4.0 technologies and products will facilitate this transition. So, in the near future, it is not unusual for robots to deliver a model lesson in science or the students solve their mathematics problems by using artificial intelligence, and probably that there's no use of working and teaching in traditional schools and universities.

\section{References}

Al Lily, A.E., Elayyan, S.R., Alhazmi, A.A. et al. Understanding the public temper through an evaluation of rumours: an ethnographical method using educational technology. Palgrave Commun 4, 141 (2018). https://doi.org/10.1057/s41599-018-0197-2

Butler, J. (2018). The Fourth Industrial Revolution and Education. South African Journal of Science, 114(5/6), 1-1. http://dx.doi.org/10.17159/sajs.2018/a0271

Ceylan, A. (2020). Book Review: Blockchain Technology Applications in Education. Journal of Educational Technology \& Online Learning, 3(2), 168-1. Retrived from https://dergipark.org.tr/en/download/article-file/1068227

Dino, M. \& Ong, I. (2019). Research, Technology, Education \& Scholarship in the Fourth Industrial Revolution [4IR]: Influences in Nursing and the Health Sciences. The Journal of Medical Investigation, 66, 3-7.

Elayyan, S. \& Al-Shizawi, F. 2019. Teachers' Perceptions of Integrating STEM in Omani Schools. Shanlax International Journal of Education. 8(1): pp. 16-21. Retrived from http://www.shanlaxjournals.in/journals/index.php/education/article/view/1136

Elayyan, S. 2016. Analytical Study of Physics Education Websites' Content. Universal Journal of Educational Research. 4(12): pp. 2832 - 2839. DOI: 10.13189/ujer.2016.041217

Retrived from http://www.hrpub.org/journals/jour_archive.php?id=95\&iid=1038

Gay, L., Mills, G. \& Airasian, P. (2012). Educational Research: Competencies for Analysis and Applications. $10^{\text {th }}$ edition. New Jersey: Pearson.

Gleason, N. (2018). Singapore's Higher Education Systems in the Era of the Fourth Industrial Revolution: Preparing Lifelong Learners. Higher Education in the Era of the Fourth Industrial. Chapter 7, 145169. Singapore: Palgrave Macmillan.

Janikova, P. \& Kowalikova, P. (2017). Technical Education in the Context of the Fourth Industrial Revolution. Open Online Journal for Research and Education. Special Issue, 65-73.

Jr, R. C. (2017, Nov 10). Educating for the fourth industrial revolution. Retrieved from http://www.universityworldnews.com/article.php?story=20171107123728676

Kim, J. R. (2017, Dec 1). Look inside the Republic of Korea's classrooms of the future. Retrieved from http://news.itu.int/education-4th-industrial-revolution-look-inside-republic-koreas-classroomsfuture/

Lee, M., Yun, J., Pyka, A., Won, D., Kodama, F., Schiuma, G., Park, H., Jeon, J., Park, K., Jung, K., Yan, M., Lee, S. \& Zhao, X. (2018). How to Respond to the Fourth Industrial Revolution, or the Second Information Technology Revolution? Dynamic New Combinations between Technology, Market, and Society through Open Innovation. Journal of Open Innovation: Technology, Market \& Complexity, 4(21), 1-24. doi:10.3390/joitmc4030021 
Liaoa, Y., Louresa, E., Deschampsa, F., Brezinskia, G. \& Venancioa, A. (2018). The Impact of the Fourth Industrial Revolution: A cross-country/region comparison. Production, 28, 1-18. DOI: 10.1590/0103-6513.20180061

Lodder, J. (2016, Feb 21). The Fourth Industrial Revolution and the Education System, how to respond? Retrieved from https://www.linkedin.com/pulse/fourth-industrial-revolution-education-systemhow-respond-john-lodder

Menon, K. \& Castrillon, G. (2019). Reimagining curricula for the Fourth Industrial Revolution. The Independent Journal of Teaching and Learning, 14(2), 6-19.

Mezied, A. A. (2016, Jan 22). What role will education play in the Fourth Industrial Revolution? Retrieved from https://www.weforum.org/agenda/2016/01/what-role-will-education-play-in-the-fourthindustrial-revolution/

Min, J., Kim, Y., Lee, S., Jang, T., Kim, I. \& Song, J. (2019). The Fourth Industrial Revolution and its Impact on Occupational Healthand Safety, Worker's Compensation and Labor Conditions. Safety and Health Work, 10, 400-408.

Molotsi, A. (2020). The university staff experience of using a virtual learning environment as a platform for e-learning. Journal of Educational Technology \& Online Learning, 3(2), 133-151. Retrived from https://dergipark.org.tr/en/download/article-file/1068222.

Neves, M., \& Ambassador, S. (2017, Jul 17). The (unknown) Impact of the Fourth Industrial Revolution in Education. Retrieved from http://blog.scientix.eu/2017/07/the-unknown-impact-of-the-fourthindustrial-revolution-in-education/

Reaves, J. (2019). $21^{\text {st }}$ Century Skills and the Fourth Industrial Revolution: A critical Future Role for Online Education. International Journal on Innovations in Online Education, 3(1), 1-21.

Schwap. K. (2016). The Fourth Industrial Revolution. Geneva: World Economic Forum.

Shahroom, A. \& Hussin, N. (2018). Industrial Revolution 4.0 and Education. International Journal of Academic Research in Business and Social Sciences, 8(9), 314-319. http://dx.doi.org/10.6007/IJARBSS/v8-i9/4593

Sharma, P. (2019). Digital Revolution of Education 4.0. International Journal of Engineering and Advanced Technology (IJEAT), 9(2), 3558- 3564. DOI: 10.35940/ijeat.A1293.129219

Waghid, Y., Waghid, Z. \& Waghid, F. (2019). The Fourth Industrial Revolution Reconsidered: On Advancing Cosmopolitan Education. South African Journal of Higher Education, 33(6), 1-9. http://dx.doi.org/10.20853/33-6-3777

World Economic Forum (2018). The Future of Jobs Reports. Geneva: World Economic Forum.

Yang, C. (2019). The Fourth Industrial Revolution, Aging Workers, Older Learners, and Lifelong Learning. Adult Education Research Conference. Conference Proceeding. Buffalo, New York. Retrieved from https://newprairiepress.org/aerc/2019/papers/35/ 